\title{
GUERRAS JUSTAS, SOCIEDAD JUSTA. AMBIVALENCIA DE DOS AFIRMACIONES ÉTICAS
}

\section{RIGHT WARS, RIGHT SOCIETY. AMBIVALENCE OF TWO ETHICAL STATEMENTS}

Rafael Larrañeta Olleta: Universidad Complutense de Madrid (España). rafael.larrañeta@mixmail.com

\section{CURRÍCULUM VITAE}

Doctor en Filosofía y Teología y profesor de Filosofía Política en la Universidad Complutense, entre otras universidades. Experto en la obra de Soren Kierkegaard. Destaca su labor articulista científico. Autor de varias publicaciones de primer nivel en el campo de la filosofía.

\section{RESUMEN}

Cualquier guerra hay que analizarla, no sólo desde el punto de vista de la propaganda mediática y de los intereses de la alta política, sino también desde el plano ético. Por lo tanto habría que ver si existe la posibilidad de que sea una guerra justa. Analizaremos aquí la conquista armada de América por parte de España y si cualquier acto malo puede convertirse en instrumento bueno para la victoria. La guerra también está unida al concepto de sociedad, y el sueño de una sociedad justa. $\mathrm{Si}$ buscamos la consonancia entre los ideales y la realidad, aparece también el concepto de justicia y el de insensibilidad. 


\title{
PALABRAS CLAVE
}

Guerra - Sociedad - Justicia

\begin{abstract}
Any war has to be analyzed not only from the point of view of media propaganda and the interests of high politics, but also from the ethical. So have to see if there is the possibility of a just war. Discuss here the armed conquest of America by Spain and if any evil act can become good tool for victory. The war also is linked to the concept of society, and the dream of a just society. If we seek the line between ideals and reality, there is also the concept of justice and insensitivity.
\end{abstract}

\section{KEY WORDS}

War - Society - Justice

\section{ÍNDICE}

\section{Preámbulo}

2. La llamada guerra justa

\subsection{Introducción}

2.2 La argumentación ética de Vitoria

2.3. España y la conquista armada de América

2.4. ¿Podemos hablar hoy de ética de la guerra?

3. El sueño de una sociedad justa

3.1. El problema de la justicia en la sociedad

3.2. Hacia una sociedad justa

3.3. Indeseabilidad de una sociedad "totalmente" justa 


\section{TEXTO:}

\section{Preámbulo}

Reúno aquí dos cuestiones éticas del tiempo presente, que están de continuo en boca de nuestros conciudadanos y a las que conviene referirse, no sólo desde el punto de vista de la propaganda mediática y desde los intereses de la alta política, sino también desde otro prisma que utilizamos a diario: el ético, pese a que lo silenciemos y lo hallemos a menudo en el fugaz candelero de la grandilocuencia política.

Por otra parte, he preferido indagar en los fundamentos de tan cruciales asuntos, en lugar de referir obras, comentarios, investigaciones, estadísticas de última hora, aun cuando sea inevitable tenerlas en cuenta.

Decían los clásicos que el fin buscado en la guerra justa es el orden y la paz. Aplicado al esquema conjunto de la vida humana, solemos afirmar que el ideal ético y político consiste en alcanzar una sociedad justa. Ambas cosas: "guerra justa" y "sociedad justa" se nos antojan con excesiva frecuencia casi como una contradictio in terminis o, siendo muy optimistas, como una utopía siempre perseguida y nunca alcanzada.

En cualquier caso, ésa es la razón que nos ha llevado a vincular ambas cosas: la posibilidad-imposibilidad de una guerra justa $y$, por ende, la posibilidadimposibilidad de una sociedad justa. 


\section{La llamada guerra justa}

\subsection{Introducción}

Todos los tratadistas dan por sentado que la ética de la guerra tiene originalmente un contexto teológico, aunque hubo que esperar a los tiempos de Francisco de Vitoria para llegar a establecer unas pautas éticas mínimas en este asunto tan doloroso para la humanidad. Como enseguida veremos, eso no significó la anulación de la perspectiva religiosa, pero la situó, al menos, en su ámbito propio.

La guerra se justificó al principio (tal como lo vemos reproducido en los integristas de todo signo) como un mandato inapelable contra los malvados que se resisten a los designios de Dios. La agresión armada y conquistadora a otros pueblos fue el eje y crisol de los proyectos esenciales que Yahvé (más tarde Alá) iba comunicando a sus elegidos. ${ }^{1}$

Dentro del Imperio romano los primeros cristianos aceptaron el hecho de la guerra como algo "natural". Algunos de ellos fueron parte integrante de las legiones y no se les exigió abandonar los artes militares para recibir la bendición de su comunidad. Esta visión se prolongó a través de la Edad Media y continuó hasta nuestros días. Los militares, que hasta hace poco eran objeto de máximo honor, siguen siendo ahora respetados en el seno de las distintas iglesias hasta el punto de que algunos son presentados como practicantes ejemplares.

Sin embargo, la crueldad de las acciones armadas ya había llamado la atención de San Agustín. El pensador de Hipona era un ferviente admirador de la grandeza imperial. De joven alimentaba con pasión el anhelo de conocer Roma. Mas, al traspasar sus muros, contempló con tristeza la degeneración y dejadez de aquellos

\footnotetext{
${ }^{1}$ Yahvé exhorta a Josué para que no tenga miedo y se lleve consigo a toda la gente de guerra. Jos, 8, 1-2. Algo similar sucede en el Corán, donde con frecuencia Dios anima al combate, p. ej. Surá 8, 65-66.
} 
romanos que se mostraron pronto impotentes para enfrentarse y detener las columnas aguerridas de los bárbaros. Ambas cosas suscitaron en él serias dudas acerca de la "bondad" del Imperio y sobre la fortaleza de sus dioses. Así nació La Ciudad de Dios como crítica pionera de la estructura política de un Estado.

Entre los temas agustinianos aparece el problema de la violencia contra otros pueblos. San Agustín denuncia la llamada "pax romana" como una falsedad, una entelequia ideológica en beneficio de las miras a menudo egoístas y crueles de los gobernadores de turno. Ello le sirve para diferenciar las guerras "justas", que se emprenden en aras del bien común, de las "injustas", es decir, las que están motivadas por la ambición o el deseo insaciable de expansión a costa de la vida y de la tranquilidad de los conquistados. De modo paralelo establece una distinción clara entre los guerreros que guardan las normas de respeto a los inocentes dentro del conflicto y quienes hallan inmisericordemente las pautas elementales de la vida. ${ }^{2}$

Santo Tomás nombra a San Agustín para establecer de una forma muy sucinta que la guerra no siempre es pecado, consagrando de hecho como válida la división de jus ad bellum y jus in bello ${ }^{3}$, división que serviría de base al "tratado" de Vitoria acerca de la guerra. Francisco de Vitoria es, en efecto, el verdadero artífice de la doctrina ética sobre la guerra y los parámetros establecidos por él no han cambiado sustancialmente hasta hoy.

\subsection{La argumentación ética de Vitoria}

\footnotetext{
2 Son muchas y muy conocidas por los clásicos, incluido Tomás de Aquino, las alusiones del obispo de Hipona al asunto de la guerra y lo hace de forma más crítica que sus sucesores. Lutero fue uno de los que más se dejó influenciar por esta actitud antibelicista, siendo expresamente vituperado por Vitoria.

${ }^{3}$ Cf. Santo Tomás de Aquino, Summa theologiae, 2-2, c. 40. Sorprende la brevedad con la que aborda este asunto. Consciente de las dificultades éticas y cristianas ante el tema, el de Aquino recuerda que, en principio, guerrear (bellare) siempre es pecado, un pecado contra la caridad, primer mandamiento evangélico. La "realidad" del orden establecido le impele a buscar aquellas condiciones (circunstancias) que deben darse para que una guerra sea justa. Ib. a. 1.
} 
Vitoria establece un principio general, que se erige en punto nuclear para cualquier tematización moral de la guerra: la injuria recibida, esto es, el único motivo "justo" es la injuria que a uno le infieren ${ }^{4}$. Por lo que expone, hay un supuesto imprescindible: que la ofensa haya sido cometida contra alguien inocente, es decir, que se trate de una injuria hecha a alguien que no ha actuado como para merecer tan mal trato ${ }^{5}$, equiparando a ella la ofensa desproporcionada, es decir, cuando se responde a un pequeño mal con una venganza o con un castigo mucho mayor y exagerado.

Mucho más importante es el fin que se proclama una y otra vez como motivo para emprender una guerra. Ese fin no consiste simplemente en una respuesta a una ofensa, porque sería una reproducción descarada de la ley de la venganza que una moral cristiana no hubiera podido menos de denunciar. El inicio de una guerra requiere una finalidad honesta.

Y para evitar abusos interpretativos por parte de los poderosos, la Escolástica enumera siete calificativos como condiciones esenciales para la guerra: causa justa, autoridad competente, justicia comparativa, recta intención, último recurso, probabilidad de éxito y proporcionalidad, que los comentaristas solían reducir a cuatro, ya que causa justa, recta intención y probabilidad de éxito son complementarios y la justicia comparativa puede sumarse a la proporcionalidad.

Como "autoridad" se definía, en tiempos de Vitoria y de Maquiavelo al Príncipe, que, a su vez y de nuevo según Vitoria, recibe toda la autoridad del pueblo. Hoy día

\footnotetext{
${ }^{4}$ La cuestión no es original, ya que está muy bien condensada en la República (334, b): "si alguien afirma que es justo dar a cada uno lo debido y entiende con ello que por el hombre justo se debe daño a los enemigos y beneficio a los amigos, no fue sabio el que tal dijo, pues no decía verdad; porque hacer mal no se nos muestra justo en modo alguno".

${ }^{5}$ Cf. F. de VITORIA, Obras. (Madrid, Bac, 1960), 825-6. He expuesto en otro lugar un comentario a estos argumentos. Cf. R. LARRAÑETA, "Ya no hay guerras justas", Ciencia Tomista, CXI (1984), pp. 307-327.
} 
hablamos de Estado como la única entidad legitimada para dictar una declaración de guerra$^{6}$. Por otro lado, la guerra como último recurso implica agotar previamente todas las vías posibles de diálogo para lograr un acuerdo que impida el conflicto.

Pero retornemos a la cuestión de fondo: ¿qué fundamentación ética subyace a esta justificación de la guerra? La respuesta es clara: aunque no es lícito matar ni herir a nadie, en caso de ataque inmerecido no se obliga a lo imposible, a lo heroico («ad impossibilia nemo tenetur»), que sería entregar la vida propia. La ética medieval lo razonaba con los criterios de la defensa legítima: entre dos vidas en juego, la mía y la del agresor, tengo derecho a preferir la propia antes que la ajena. El argumento de la defensa legítima, aplicado a la sociedad y utilizado como medio "preventivo" o "ejemplar", ha amparado todo uso de la violencia dentro de la ética cristianooccidental. Se reconoce como más perfecta ${ }^{7}$ la actitud de quien prefiere morir antes que matar, pero la "norma naturae" de la vida humana no llega tan lejos. En algún sentido ya Santo Tomás optaba por los principios aristotélicos al margen o por encima de los cristianos.

Volvamos a la guerra. Cuando uno sufre en su cuerpo, en sus familiares o compatriotas una agresión inmerecida, opta justamente por la muerte del enemigo antes que la de sus seres queridos. Si nadie le hace justicia, si no encuentra otra forma de reparar su fama, si no se le devuelven sus propiedades ${ }^{8}$, su patria, sus hijos, tiene pleno derecho a declarar la guerra al usurpador.

\footnotetext{
${ }^{6}$ C. Schmitt establece una clarificación importante: el verdadero enemigo es el el enemigo público (hostis), no el privado (inimicus). La guerra como tal sólo se da entre Estados. Todo ello afecta a la entraña mismo de "lo político", que no viene determinada por la lucha entre Estados, pero sí por la posibilidad de que acaezca. Cf. C. Schmitt, El concepto de lo político, Alianza, Madrid, 1998, pp. 59-68.

${ }^{7}$ Santo Tomás lo exige a los clérigos. Summa theologiae, 2-2, c. 40, a. 2.

${ }^{8}$ Vitoria insiste en este aspecto, que estaba recogido ya en las Pandectas. Cf. F. de Vitoria, De indis, pp. 851-856. Cf. también, R. Larrañeta, Tras la justicia, san Esteban, Salamanca, 1999, pp. 33-34.
} 
De aquí no se deriva una legitimación incondicional de la violencia. Tampoco basta cualquier injuria para declarar una guerra9. Se condena incluso como inmoral la disposición para enrolarse en cualquier guerra, sea justa o no su finalidad ${ }^{10}$, aunque en última instancia prime el sí ético a la guerra. Por eso hubo tantas y tan serias discusiones entre los éticos acerca de la bondad moral de las luchas contra infieles, contra los indios de América, contra otros cristianos.

Pese a la proclividad a cohonestar las diferentes causas de una guerra, los moralistas clásicos, amparados en la tristísima experiencia de tantas calamidades como en ellas se suscitan, señalaron siempre notables limitaciones a la actividad bélica. Era patente cierto escrúpulo al basar la justicia de la guerra en argumentos indirectos, aunque fueran de corte bíblico. Quizás intuían que tal actitud no era sino la continuación disfrazada de la ley del Talión ${ }^{11}$.

La mayor limitación ética a la guerra provenía del argumento de proporcionalidad. Se aceptaba, como norma general, que ningún fin bueno justifica los medios malos y, por ello, se condenaba radicalmente la muerte de inocentes, pese a que nunca logró detener del todo el horror de las distintas guerras. En todo caso, nadie dudaba de que la guerra es inmoral si de ella se derivan mayores males que bienes ${ }^{12}$. Frente a esto, las llamadas al honor herido o al patriotismo humillado de quien deseaba la muerte ante que una vida sin honor, pasaban a un segundo plano.

\footnotetext{
${ }_{9}^{9}$ Lo enuncia en su conocida Relección sobre el Poder Civil. Cf. F. de Vitoria, De potestate civili, Obras, pp. 167-168.

${ }^{10}$ Cf. F. VITORIA, Comentarios a la II-II de Santo Tomas, Salamanca, 1932, II, 225. Buscando secularizar y dar mayores dosis de realismo a la cuestión, Grocio se esfuerza por establecer unas lindes divisorias entre los diferentes participantes en una contienda, aludiendo a su condición (militares frente a agricultores o mercaderes, mujeres, niños, etc.). Cf. H. Grocio, Del derecho de la guerra y de la paz, Ed. Reus, Madrid, 1925, t. IV, pp. 112-142.

${ }^{11}$ Grocio la invoca abiertamente, cuando propone que esta ley se aplique sólo contra quien delinquió. Ib., t. III, p. 347.

12 Vitoria, De potestate civili, p. 167.
} 
Otra duda sobre la ética guerrera procedía de lo que ahora solemos calificar como "objeción de conciencia". Al súbdito podía constarle la injusticia de una guerra emprendida por un príncipe cristiano. Su deber era negarse a participar en tal empresa. Es otro indicio de que la licitud ética de la guerra no les era evidente ${ }^{13}$. Igual síntoma hallamos en la cualificación de la justicia de la guerra: puede haber causa buena por ambas partes y casi nunca existe justicia absoluta por un solo lado ${ }^{14}$. Esto explica el fenómeno de una guerra declarada "santa" por ambos contendientes ${ }^{15}$.

Quedan pendientes todavía los topes éticos al desarrollo de la guerra, eso que se designó con el nombre de "jus in bello". Que una guerra haya sido emprendida de buena voluntad no da derecho a todo género de tropelías, abusos y muertes. El mismo derecho internacional ha ido progresando paulatinamente hasta que en el siglo XX se concordaron una serie de normas internacionales sobre el trato a los prisioneros ${ }^{16}$.

Por último y dadas las múltiples arbitrariedades que llegaron a oídos de los éticos, se estableció como contrario a la ética todo abuso de los argumentos legítimos para una guerra ${ }^{17}$.

\footnotetext{
${ }^{13}$ Cf. Vitoria, Obras, p, 831; Comentarios a la 2-2, II, p. 233. Sin embargo, Vitoria defiende que la fortaleza del Estado exige la obediencia a los llamamientos de guerra, porque, si no, podría peligrar la existencia misma de la república.

${ }^{14}$ F. Vitoria, Obras, pp. 712-713 pero siempre sitúa la "causa justa" de un lado, admitiendo en el otro la excusa de la "ignorancia invencible". Ib., p. 838.

${ }^{15}$ Eso debiera bastar para desenmascarar la falsa sacralización de las guerras. El error de las Cruzadas fue precisamente su santificación.

${ }^{16}$ Me refiero a la Convención de Ginebra. Sobre su origen en Grocio, cf. A. TRUYOL, F. de Vitoria y H. Grocio: cofundadores del derecho internacional, "Ciencia Tomista" 111 (1984) pp. 17-27.

17 Éste es el motivo por el que Vitoria se decide a escribir la primera parte de su Relección De Indis. Cfr. F. VITORIA, Obras, p. 648.
} 
No obstante, es evidente la debilidad de las argumentaciones invocadas para moralizar la guerra. Aun cuando parezcan una respuesta "adecuada" a los violentos, casi siempre se transforma en abusos y matanzas. Por eso conviene matizar.

La expresión "guerra justa" hace pensar en un aprobado ético a un fenómeno tan antiguo. Las apariencias engañan. Por si no bastaran las cortapisas que conlleva el sí ético a la guerra (proporcionalidad, causa buena, consecuencias tolerables, etc.), se añade un juicio determinante: la guerra aparece siempre como mal menor. Jamás puede concebirse desde la ética una apología de las acciones armadas contra los semejantes, una calificación de la guerra como meta moral. En una palabra, la guerra es un mal. Y, además, origina otros males y pesares. Es el punto de partida experiencial de los éticos en todas las épocas, también de Vitoria. Pero como en determinadas ocasiones la guerra se torna inevitable, en otras es la muestra heroica de cómo defender al inocente y, a menudo, es la "mejor" manera de restablecer la justicia y la paz ya que impide el empeoramiento de situaciones pésimas, los éticos creyeron y creen que quizás no merece un "suspenso" tan drástico. No se olvide que la salida moral para tales situaciones fue siempre "media" al estilo aristotélico: es un mal inevitable, es un camino torcido hacia la recta senda, es un medio "obligado" hacia el bien. Pero camino o medio, la guerra sigue siendo un mal a evitar y un peligro a conjurar.

\subsection{España y la conquista armada de América}

Una vez establecidos los principios sobre el origen del poder, sobre la ciudadanía y sobre los derechos de propiedad 18 , Vitoria se topó con un novísimo problema: el derecho de España a posesionarse de los territorios recién descubiertos en ultramar y, como medio casi imprescindible, la intervención bélica en aquellos lejanos e ignotos parajes. El tema no era baladí. Por un lado, los que habían vuelto de los viajes

${ }^{18}$ Cf. R. Larrañeta, Tras la justicia, pp. 33-34. 
narraban cosas fantasiosas acerca de las ilimitadas riquezas que allí podían hallarse y que parecían no pertenecer a nadie. Por otro, los misioneros de las distintas órdenes religiosas describían de palabra o por escrito un sinfín de vejaciones, arbitrariedades y tropelías a que eran sometidos los aborígenes, causando en ellos desolación, enfermedades y muerte. Por si fuera poco, el mismísimo Emperador parecía tener interés en conocer la opinión de los moralistas, teólogos y juristas en todo lo referente a los descubrimientos de ultramar ${ }^{19}$. Éste es el motivo por el que el catedrático, pese a su prudente silencio anterior, se decide a hacer públicos sus pensamientos en torno a una causa tan controvertida, ya que con ella entraban en juego los intereses cortesanos y el tribunal siempre temible de la santa Inquisición.

En la Parte Primera de la Relectio de Indis recenter inventis, Vitoria pone sumo esmero en destacar que los monarcas españoles se atienen a los dictados de la ética y que, por ello, están dispuestos a escuchar abiertamente los consejos de los teólogos y jurisconsultos. Da por sentado, además, que los indios ya están en poder de los españoles y pregunta, por ello, qué potestad civil tienen allí los reyes de España y, como añadido, si hay alguien que goce también de poder espiritual sobre ellos.

El desarrollo es muy sencillo: rechaza los que llama "títulos ilegítimos" y explica el alcance de los "títulos legítimos", añadiendo una coletilla esencial: la cuestión americana no es tan evidentemente justa o injusta que no pueda discutirse ${ }^{20}$.

El arranque resulta curioso: el derecho de propiedad. Para desmontar la tesis de que estos seres humanos son "naturalmente" esclavos acude al argumento de que, antes del descubrimiento, eran dueños pacíficos de sus $\operatorname{cosas}^{21}$. Luego no eran siervos,

\footnotetext{
${ }^{19}$ Cf. F. de Vitoria, Doctrina sobre los indios (De indis recenter inventis relectio prior), San Esteban, Salamanca, 1992, p. 104. Citamos por esta edición facsimilar preparada por R. Hernández.

${ }^{20} \mathrm{Ib} .$, p. 105.

${ }^{21} \mathrm{Ib} .$, pp. 109-110.
} 
afirma, ya que éstos carecen de todo derecho de propiedad. Una dialéctica similar utiliza para negar que algún pecado pueda privarles de ese derecho, porque ni siquiera los herejes lo pierden. La conclusión es radical: nadie es siervo por naturaleza 22 .

El rechazo de los títulos ilegítimos entra de lleno en el contexto de la reflexión ética sobre la guerra, no en vano la segunda relección habla del "derecho de guerra de los españoles contra los bárbaros"23. Después de oponerse a la legitimidad de los mismos (autoridad papal o real sobre el orbe, pecados contra naturam, etc.), Vitoria insiste en el punto de la ignorancia invencible que exime de culpa, sin dejar de denunciar que los atacantes españoles tampoco están libres de faltas.

Entre los títulos legítimos para iniciar esta peculiar guerra de conquista nos choca el de la propagación de la fe, aunque algo tendrá que ver con la contemporánea exigencia de tolerancia para los adeptos a otros credos. Sobresalen, en cambio, por su constante vigencia los siguientes: apoyo a lo que la mayoría del pueblo ha decidido, defensa de los inocentes frente a una injuria gratuita o una muerte injusta y, sobre todo, el derecho de tránsito por un territorio extraño, supuesto que sea con buenas intenciones (mercaderes con sus caravanas comerciales al estilo de la ruta de la seda), algo que incluye a la vez el derecho a asentarse en otra nación, gozando de los privilegios de ciudadanía en situación de paridad 24 .

Vitoria establece una pautas conclusivas: si la expedición armada de España en América se basa en el primer tipo de razones éticas, "mal se ha contribuido a la

\footnotetext{
22 "...nullus est servus a natura". Ib., p. 73.

23 "De indis, sive de iure belli hispanorum in barbaros, relectio posterior".

${ }^{24}$ Ib., pp. 137-146.
} 
salvación del príncipe"25, pero, si se apoya en las últimas, será de gran ayuda a la actividad comercial, se engrandecerá el poder y el prestigio real y se contribuirá a la permanencia en la fe de los primeros convertidos al cristianismo. Contando con el talante de las gentes de armas, con los conflictos que puedan originarse y ya se han originado frente a los aborígenes, con la ambición de algunos conquistadores (encomenderos), una actuación que se atenga a los principios éticos formulados sería un proceder ecuánime y justo, mientras que abandonar de pronto esa empresa constituiría una grave dejación de las responsabilidades contraídas ${ }^{26}$.

\section{4. ¿Podemos hablar hoy de ética de la guerra?}

Vitoria fue el modelo de docente que sistematiza los conocimientos adquiridos y les proporciona una forma de comprensión concorde con su tiempo. Sus pronunciamientos sobre la guerra tuvieron eco inmediato en autores tan relevantes como Francisco Suárez ${ }^{27}$ y Hugo Grocio, considerados los tres en conjunto como los grandes impulsores del derecho internacional.

Si hacemos un juicio previo, notaremos que Vitoria se sitúa en un contexto polémico, tanto por la vertiente teórica como por la urgencia práctica de la arrolladora novedad de los acontecimientos americanos. Como sabemos, el maestro salmantino discrepa del pacifismo inicial de Lutero (quebrado luego por la revolución de los campesinos de Müntzer) y del realismo implacable de Maquiavelo (pese a que éste se oponía a cualquier acto gratuito de crueldad por parte de los jerarcas). Eso explica la insistencia de Vitoria en no perder nunca de vista los parámetros éticos que excusan

\footnotetext{
${ }^{25} \mathrm{Ib} .136$.

${ }^{26} \mathrm{Ib} .$, p. 147.

${ }^{27}$ Como sabemos, su obra De legibus es un punto de referencia fundamental para las cuestiones políticas. El problema de la guerra lo aborda en la Disputatio 13, bajo el epígrafe De bello (Cf. L. Pereña, Teoría de la guerra en Francisco Suárez, Madrid, 1954), añadiendo importantes matices en determinados aspectos.
} 
(más que justifican) el inicio de una guerra y su empeño en oponerse con toda energía a cualquier agresión guerrera fuera del control de la legítima autoridad.

Además, Vitoria inserta la cuestión de la guerra en la virtud teologal de la caridad: todo acto contra la paz hiere gravemente el orden del amor cristiano. Algunos han criticado que no remitiera el tema al tratado de justicia ${ }^{28}$, resaltando que la injuria al inocente rompe la ecuanimidad en el trato debido a otra persona o a un conjunto de personas. Pero esos críticos olvidan que esta manera de abordar tan espinoso asunto le permite a Vitoria hablar prácticamente siempre de "licet", "está permitido" según el orden del derecho natural, responder adecuadamente a la ofensa ${ }^{29}$. Como he indicado antes, nunca se dice: "es bueno" repeler al agresor, tal como podría inferirse de un acto de "justicia", porque herir al prójimo infringe el primer mandamiento divino.

No nos resulta extraño que, a la hora de hablar de la ética de la guerra, un tratadista tan actual como M. Walzer invite simplemente a releer las obras de Santo Tomás, Vitoria, Suárez y Grocio, porque, en el fondo, está persuadido de que, en principio, no existen más argumentos morales que los expuestos y sólo resta reexaminarlos una y otra vez a la luz de las nuevas circunstancias ${ }^{30}$. Walzer piensa que las posturas frente a este triste fenómeno social son siempre las mismas: o se afirma, con el más crudo realismo, que la guerra está más allá del juicio moral, o se defiende que ninguna guerra es justificable éticamente, tal como proclaman los pacifistas, ya que en la contienda cualquier acto malo puede convertirse en instrumento "bueno" para

\footnotetext{
${ }^{28}$ Suárez lo especifica: "Bellum, quod iuxta praecedentem conclusionem zine legitima authoritate indicitur, non solum est contra charitatem, sed etiam contra iustitiam", De bello, Sect. $2^{\mathrm{a}}, 6$.

${ }^{29}$ En este párrafo aparece con cierta claridad la distinción a que aludimos: "Hoc non passim et ex quacumque causa belli justi licet facere...". Se refiere a la defenestración de los príncipes enemigos. Cf. Vitoria, Obras, p. 856.

${ }^{30}$ Cf. M. Walzer, Guerras justas e injustas, Paidós, Barcelona, 2001, pp. 21-22.
} 
la victoria y sin olvidar que por sí misma la guerra carece de limitación ${ }^{31}$ con lo que la muerte y la desolación pueden agudizarse hasta el infinito

Si ensayamos una conclusión sobre lo dicho hasta aquí, tendremos el siguiente listado:

$\left.1^{\circ}\right)$ La guerra justifica (hace justos) los actos malos.

$2^{\circ}$ ) La guerra tolera incluso la comisión de acciones éticamente pésimas.

$\left.3^{\circ}\right)$ La guerra posee una "lógica" que desdeña el respeto a la vida.

$4^{\circ}$ ) Las guerras confrontan Estados, reduciendo a la nada la importancia y el papel de los individuos.

$5^{\circ}$ ) La guerra no proporciona argumentos fiables que configuren una decisión razonable de los participantes (haría peligrar la fortaleza de cada nación: razón de Estado).

$6^{\circ}$ ) La guerra se convierte en un infierno personal, ya que esclaviza la capacidad de juicio de los soldados e ignora los cauces cotidianos de la actividad democrática.

$7^{\circ}$ ) Por sí misma la actividad bélica siempre es éticamente mala, ya que planea y ejecuta la desaparición de los contendientes contrarios.

$8^{\circ}$ ) Frente a la guerra sólo cabe pensar en su desaparición.

${ }^{31}$ Cf. C. von Clausewitz, De la guerra, Barcelona, Idea Books, 1999. 
Cuando todos pensábamos que, con el nuevo milenio, las guerras pasarían a la añeja historia de las confrontaciones tribales, nos hemos despertado de pronto ante un agravamiento terrible e inesperado de las mismas, suscitado por los terrorismos de distinto signo, por las rupturas étnicas, nacionalistas y religiosas, por las disputas fronterizas, quedando aún en el abismo de los milenarios temores el acuciante problema de la presión demográfica en algunos países superpoblados y hambrientos. Habrá que esperar, de nuevo, tiempos mejores.

Pero la guerra desaparecerá irremediablemente y nosotros tenemos el reto de continuar la tradición vitoriana, proponiendo alternativas realistas ${ }^{32}$. De hecho, la humanidad ya ha puesto en marcha algunas: Declaraciones de Derechos, Organismos internacionales de decisión y control, Tribunales de justicia para los crímenes de guerra, Encuentros frecuentes de los máximos dirigentes de cada país, contacto ilimitado de los jóvenes de diversas nacionalidades. Aunque su eficacia no satisfaga, constituye un paso esencial hacia adelante.

No obstante, queda todavía un largo trecho para enraizar en todos los pueblos la cultura de la tolerancia y el aprendizaje de una ética mínima frente al extraño. Con ella, la sabiduría y la bondad natural borrarían del mapa tantos odios y tantos rencores, fruto falaz, casi siempre, de la ignorancia y de los prejuicios infundados.

\section{El sueño de una sociedad justa}

\subsection{El problema de la justicia en la sociedad.}

¿Qué fue al comienzo la justicia: una exigencia ética, un resorte social o un problema político? La pregunta no es baladí, porque el color de la respuesta originaria podría proporcionar pistas importantes.

\footnotetext{
32 Walzer añade al binomio clásico de jus ad bellum-jus in bello, un tercer contenido: jus post bellum. Cf. R. Grasa, Introducción a M. Walzer, Guerras justas e injustas, p. VI.
} 
Si aproximamos lo social y lo político a lo legal, comprobamos que, desde tiempos remotos, el asunto fue circunscrito a los rígidos dominios, casi siempre manipulados, de la impartición del derecho, reservando a las diferentes instancias (jefes, ancianos, consejos, monarcas, reyes, sacerdotes) la resolución de los muchos conflictos que provoca la convivencia.

El talante ético de la justicia quedó confiado y reducido a la sensibilidad de los miembros de un tribunal, al pozo dejado por los relatos míticos, a los comentarios benévolos de los promulgadores de leyes o, en el mejor de los casos, a las palabras consagradas de los fundadores de religiones (Buda, Jesucristo, Mahoma). Pero de suyo, la situación general de desproporción entre individuos, entre estamentos, entre castas, entre etnias, entre pueblos, se aceptaba como algo inevitable, como una imposición de la naturaleza e incluso como un avatar insoslayable del curso vital.

Siempre tan perspicaces, los griegos formularon enseguida, por boca de Platón, una duda primordial acerca de la vinculación inexorable entre algunos de estos "conceptos". Para mayor claridad, me he permitido ordenar las afirmaciones platónicas ${ }^{33}$ del siguiente modo:

$\left.1^{\circ}\right)$ ¿Qué es justo: dar a cada uno lo que le es debido

o darle lo que le es proporcionado?

$\left.2^{\circ}\right)$ ¿Es justo dar al amigo lo BUENO

y al enemigo lo MALO?

$\left.3^{\circ}\right)$ ¿Es justo dar BIEN al amigo BUENO o al enemigo BUENO

y dar MAL al amigo MALO y al enemigo MALO?

${ }_{33}$ PLATON, República, 331a-336b. 
$\left.4^{\circ}\right)$ ¿Es justo en alguna circunstancia dar MAL?

La respuesta al último interrogante es contundente: NO, no es justo DAR MAL, porque los justos/buenos no pueden hacer a nadie justo/bueno CON EL MAL.

Los términos iniciales del interrogatorio se han complicado. Como gran equivalente de la justicia aparece una categoría ética: hacer/dar el bien-hacer/dar el mal, y se equipara con ellos al destinatario de ese bien/mal, es decir, al amigo/enemigo y, con un paso más, el amigo/bueno-enemigo/bueno el amigo/malo-enemigo malo, adjuntando por ende otras categorías: lo debido o proporcionado a quien recibe ese bien-mal.

No es difícil colegir que la mezcla de todos estos elementos puede dar lugar a una enorme complejidad de razonamientos $\mathrm{y}$, de hecho, eso fue lo que aconteció al desarrollarse los grupos sociales y aflorar nuevos entes políticos.

Aristóteles daría un giro notable a esta reflexión, situando los contenidos de la justicia en la esfera ética. La justicia es la máxima excelencia (virtud) del individuo, afirma, porque tiene como objeto preferente el bien común, es decir, en cuanto al sujeto la prudencia está en la cúspide, pues atañe a la suprema facultad de los hombres (la razón), y en cuanto al objeto sobresale la justicia, ya que tiene en consideración el bien de todos, muy superior al bien de un solo hombre particular.

Pero al Estagirita no le resultan sencillas las fórmulas de aplicación de la justicia y, por ello, se esfuerza en establecer distinciones sutiles en su aplicación, como las de proporción, conmutación y distribución, distinciones que sirvieron mucho en el ámbito legal y menos en la esfera del equilibrio ético de las sociedades. 
No es una novedad denunciar a Aristóteles como el causante del alejamiento entre lo social y lo ético, olvidando el ritmo interno de los acontecimientos históricos. Y si bien es cierto que el talante de sus propuestas primó en muchos momentos sobre otro tipo de consideraciones, quienes formulan este juicio antiaristotélico pasan por alto dos aspectos: por un lado, el mantenimiento de la referencia ética fundamental hubiese sido muy fructífero para el progreso del respeto a las exigencias del individuo como persona; por otro, las imposiciones de la realidad provocaron el olvido de la altísima consideración de la ciudad como supremo bien y la demanda de lograr para ella ciudadanos probos, aun cuando éstos no logren cumplir las máximas metas del orden ético ${ }^{34}$.

Mas la lección aristotélica no había surgido de la nada. La respaldaba toda una tradición que exaltaba los valores fundantes de esta concepción de la ciudad. En su discurso fúnebre, Pericles había marcado las pautas de la ciudad, la ciudad entendida como agrupación perfecta de quienes la componen, tan perfecta que sirve de modelo para otras ciudades.

Para Pericles, los valores más sobresalientes de La ciudad (Atenas) son dos:

1) La isonomia, que tiene, a su vez, una doble vertiente:

- igualdad de derechos, en virtud de la cual todos son iguales para resolver las diferencias privadas.

- igualdad política, porque se acepta como justa la decisión de la ciudad que siempre está mirando y velando por el interés de todos los ciudadanos.

2) La libertad en la ciudad, por la cual cada uno actúa libremente, siendo la ley de la ciudad la dueña, el rey de todos ${ }^{35}$.

\footnotetext{
${ }^{34}$ ARISTOTELES, Política, Lib. II y VII.

${ }^{35}$ TUCÍDIDES, Historia de la guerra del Peloponeso, Lib. II, 34-48.
} 
Como puede percibirse a primera vista, los griegos no se conformaron con establecer resortes militares o políticos para una buena ciudad, sino que señalaron unas pautas muy consonantes con la ética y con los valores más apreciados por el pueblo.

No es extraño que, pocos siglos después, Cicerón replanteara la cuestión en forma de interrogante radical: ¿puede existir una ciudad injusta, esto es, puede considerarse como república una asociación injusta de individuos?

La respuesta ciceroniana es bien conocida: "¡De ningún modo!" Contra quienes opinan que es imposible gobernar realistamente la república sin injusticia, el cónsul romano defiende que sin una gran justicia no puede gobernarse ni subsistir la República. ¿Qué es pueblo (res-publica)? No una reunión cualquiera de individuos, sino una asociación basada en el consentimiento del derecho y en la comunidad de intereses. El pueblo deja de ser pueblo cuando es injusto, cuando no hay derecho ni comunión de miras ${ }^{36}$.

Un milenio después y comentando la política de Aristóteles, Tomás de Aquino estableció unas conclusiones que aún chocan a muchos, al oír el nombre de su autor:

$1^{\text {a) }}$ la ciudad realiza el contenido de la justicia en cuanto tal.

$2^{\mathrm{a}}$ ) La ciudad es el bien supremo (bonum principalissimum), porque condensa en sí el bien que todos desean y que es superior a cualquier bien individual.

$\left.3^{a}\right)$ ¿Quién es el verdadero ciudadano? El que participa en la justicia de la ciudad, en vivir y defender la justicia.

${ }^{36}$ MARCO TULIO CICERON, Sobre la república, Lib. III. 
$\left.4^{\mathrm{a}}\right)$ ¿Pueden y deben ser todos ciudadanos "plenos" (studiosi)? Sí, y con ello se hacen partícipes del bien de la justicia de la ciudad.

$\left.5^{a}\right)$ ¿Pueden y deben ser ciudadanos buenos (viri boni) en sentido ético? Sería deseable, pero resulta irrealizable. Basta con que sean "buenos ciudadanos" ${ }^{137}$.

Aparece así la idea de lo justo político, que es suficiente para la realización de un modelo perfecto de ciudad.

La ciudad consiste en cierta comunidad de vida, ordenada a la suficiencia de sí en aquello que atañe a la vida. Para poder cumplir ese objetivo, se precisa que reine en la ciudad lo que califica de "justo político" y que tiene tres requisitos previos: $1^{\circ}$ ) Que se halle entre personas libres. $2^{\circ}$ ) Que se realice entre personas iguales. $3^{\mathrm{a}}$ ) Que concierna a quienes son sujetos plenos de la ley (no a esclavos privados de libertad).

Con estas miras, se entiende la exigencia de elegir un gobernante dispuesto a custodiar lo justo político, a respetar y fomentar el respeto a la libertad, la igualdad y la ley. También podemos pensar con ello en una simbiosis adecuada entre justicia y política, lo cual nos aclara el interrogante inicial.

\subsection{Hacia una sociedad justa}

Buscando la consonancia entre los ideales y la realidad, Santo Tomás hurgó, además, en los entresijos de la justicia que, ya en su tiempo, se había transformado en derecho (sin duda, por la emergencia del derecho romano, recuperado del olvido multisecular de Occidente, pese a las abundantes huellas dejadas en las legislaciones civiles y eclesiásticas). Esa búsqueda le condujo a preguntarse por las raíces del término y del concepto de justicia.

\footnotetext{
${ }^{37}$ Cf. T. AQUINO, In VIII Libros Politicorum Aristotelis.
} 
La etimología proporciona dos pistas elocuentes:

$1^{\mathrm{a}}$ ) Jus procedería, por un lado, de yu (yu-gum, jungere, ayuntamiento), indicando la unión que se establece entre personas y la sumisión exigida a muchos.

$2^{\circ}$ ) Jus aludiría, por otro lado, a yoh, partícula sacra, tal como la vemos en JupiterJovis o en jurare.

Aunque se buscó establecer una división entre jus sacrum y jus humanum (naturale), adecuable a esta doble fuente, el hecho es que cada acto jurídico conservó (y aún conserva en muchos sentidos) el triple contenido: la justicia en su acepción griega, el imperio del derecho entre los ciudadanos y el respaldo de la autoridad divina.

Sin embargo y con el paso del tiempo, el dominio del juris se transformó, emergiendo un nuevo término: derecho, traducción literal de jus, pero con derivaciones muy distintas.

En efecto, derecho se origina en el sánscrito rgu, que señala lo derecho (lo no torcido ni curvo) en sentido físico y moral y de ahí las palabras right, recht, ret y rigtigt, diritto, droit, etc. Lo sujeto a derecho implicaría, por todo ello, la rectitud ética y legal de la acción emprendida.

Aún resta otra aclaración, si nos remitimos a la etimología griega de derecho. Derecho (dikaios) procedería del sánscrito dica, vía recta (S. Tomás) o, (según Aristóteles) de dijós (en dos), cuya raíz está presente, por ejemplo, en dicotómico, dual, duda. La riqueza del significado estriba en señalar dos partes iguales, cuya aplicación ética es singular: "Justum est aequale et iniustum inaequale". El medio excelente (virtuoso y legal) consiste en la ecuanimidad o proporción. 
Toda esta acumulación de sentidos hacen comprensible la llamada de atención acerca de los límites de la ley jurídica, tal como hoy la entendemos, es decir, aun cuando habitualmente la lex suele identificarse con el jus y, por tanto, la lex naturalis con el jus naturale, conviene no olvidar que "lex nos est ipsum jus proprie loquendo, sed aliqualis ratio juris".

¿En qué consiste, entonces, el jus como tal, jus en cuanto justo y legal? Tres notas lo explicitan: que sea en orden a otro, que sea algo debido y que se deba en estricta igualdad. Pero rigurosamente hablando el Jus es una facultad moral de la persona, culminada en el objeto debido a ella y constituyendo una unidad con la persona"38.

Sentados por Grecia los principios de realización de un régimen estatal basado en la justicia (lo que ahora llamamos democracia) y establecidas desde el Medievo las vinculaciones teóricas entre lo justo y lo jurídico, el constitucionalismo inglés y la inestimable ayuda reflexiva de autores como Locke, Montesquieu, Hume y, sobre todo, Hobbes, lograrían dar cuerpo a una estructura política asentada en la realidad.

Pero la modernidad percibía la carencia práctica de unos baremos sociales adecuados a esa libertad "formal" y que no eran otros sino los englobados en los polémicos contenidos de la propiedad. La búsqueda de la igualdad en la vida política y social se transformó una y otra vez en la lucha feroz por la igualdad económica. Y en ello ha gastado la humanidad muchos siglos de civilización, de cultura y de paz.

¿Por qué ha sido tan acre esta "nueva" expedición hacia la conquista de una aspiración eternamente presente en el corazón de los humanos? Porque topamos, por una parte, con la índole siempre egoísta de los individuos y, por otra, con la

${ }^{38}$ T. AQUINO, Summa theologiae, II-II, qq. 57-58. Cf. la esmerada introducción de T. URDÁNOZ, Introducción al tratado de la justicia, Ed. BAC, Madrid, 1956, pp. 178-231. 
formidable complejidad de un cambio político, social y económico de tanta envergadura.

Agnes Heller ha dado forma reciente a todos estos planteamientos con una pregunta algo sofística: ¿es conveniente y necesaria una sociedad completamente justa? Y antes de explicar su propuesta ${ }^{39}$, es obligado advertir que dicha pregunta, a la que todos responderían espontáneamente con un sí radical, contiene ambivalencias previas importantes. Sin ellas hubiese sido imposible enunciar tan atrayente propuesta.

Heller constata que, después de tantos siglos de debate, sigue persistiendo el interrogante esencial sobre la justicia política. Para dilucidarlo, la autora pretende llegar a un concepto ético "incompleto" de justicia, con el cual podríamos establecer un fundamento normativo común para diferentes formas de vida. ¿Cómo razona estos presupuestos? ¿Por qué se conforma con esta especie de inconclusión de la justicia? Veamos sus razonadas respuestas.

Aunque el aspecto de las normas justas es el bien, nunca podemos soslayar que las que reconocemos como "normas justas" son sólo y siempre normas sociopolíticas. Por ello no resulta desmesurado confesar que ningún concepto ético-político de justicia puede pretender diseñar la mejor forma posible de vida, la mejor en sentido real y en sentido ético. De ahí la negativa inicial al problema formulado: ningún proyecto de justicia se adecua a la plenitud añorada, máxime si le aplicamos el adjetivo de "completa". La justicia es un concepto camaleónico: lo que hoy aplaudimos como justo, mañana lo condenamos como injusto.

Para no dejarnos en una especie de vacío social respecto de la justicia, Heller formula escalonadamente sus argumentos:

${ }^{39}$ Cf. A. HELLER, Más allá de la justicia, Crítica, Barcelona, pp. 281-292. 
$1^{\circ}$ ) Todas las sociedades han sido justas, es decir, han sido justas en cuanto legítimas y legitimadas por sus defensores.

$2^{a}$ ) Todas las sociedades han sido, a la vez, injustas, porque en ninguna de ellas ha quedado erradicada la explotación de muchos individuos y grupos sociales.

$3^{\text {a) }}$ La denominada "sociedad justa" es algo que siempre ha estado y está ahí delante en cualquier época y área geográfica, pero sólo como un fantasma, una fantasía, una utopía que todos persiguen y deben intentar alcanzar, aunque nunca lo logren.

$4^{\mathrm{a}}$ ) En definitiva, es posible una sociedad justa, tal como las hemos conocido, pero obviamente no es conveniente ni deseable.

$5^{\mathrm{a}}$ ) Por si esto no bastara, una sociedad justa perfilada como algo ya hecho y culminado encarnaría el concepto estático de justicia. Seríamos privados para siempre del rico dinamismo de la historia humana. Por otra parte, el referente de "justicia" supone su contrario, la injusticia: en un supuesto estado de perfecta justicia perduraría por definición la injusticia. Si, para obviar la dificultad, soñáramos en un mundo sin normas, Marx sería el primero en objetarlo.

En resumen, Heller sostiene que el mejor mundo "moral" es un mundo en el que pueda haber "mal", esto es, en el que puedan denunciarse como malas y perversas determinadas acciones públicas o privadas de los individuos y de las colectividades $^{40}$.

¿Qué pretenden, entonces, quienes defienden que el proyecto de una sociedad completamente justa no debe ser enseñado ni transmitido con ligereza?

\footnotetext{
${ }^{40}$ Ibid. 290-292.
} 
Las pretensiones de quienes se resisten a hablar en términos de utopía podían resumirse en estas tres proposiciones:

$\left.1^{a}\right)$ Sentar desde el inicio normas y reglas sociopolíticas, eso que solemos consagrar en las democracias modernas con el término de leyes fundamentales y en el contexto mundial con el título, por ejemplo, de Carta o Declaración de los derechos del hombre.

$2^{\mathrm{a}}$ ) Establecer, ante todo y por encima de todo, los procedimientos para fijar como justas o injustas esas normas y reglas sociopolíticas.

$3^{\text {a }) ~ F r e n t e ~ a ~ l a ~ d i s y u n t i v a ~ d e ~ u n ~ s o l o ~ t i p o ~ d e ~ n o r m a s ~ o ~ u n a s ~ n o r m a s ~ c o m p a r t i d a s, ~}$ inclinarse siempre en favor de la segunda posibilidad, ya que con ello se vuelve más fluida y realizable una vida en armonía, lo que Kant llamaba la "paz universal".

Flotan en el aire muchas dudas. ¿Qué es justicia en general? ¿Qué es justicia política? ¿Cuál es la mejor y más eficaz guía para la vida de los pueblos?

\subsection{Indeseabilidad de una sociedad "totalmente" justa.}

Choca, sin duda, la fórmula literal de esta conclusión, pero la explicación de la misma será capaz de resolver este primer pasmo.

Un proyecto de sociedad "tan" justo no parece deseable, porque difícilmente imaginamos cómo podría asentarse en la realidad. En el foro interno muchos juzgamos como imposible un plan tan idealista.

Si de nuevo dirigimos la mirada al pasado, podemos inferir con facilidad que hablando de "sociedad justa" sobrentendieron cosas muy dispares: 
$1^{\circ}$ ) Con el término de "sociedad justa" los griegos de la época dorada de Atenas pintaron aquel marco de vida creado para los iguales y cuyos rasgos fueron pulcramente trazados por Pericles: una sociedad donde la subsistencia de los políticos estaba garantizada, el disfrute de las prerrogativas asamblearias era pleno, las responsabilidades se repartían con cierta ecuanimidad, etc.

$2^{a}$ ) Una sociedad justa apeló también y obligatoriamente a la impartición de la justicia. En ese ámbito todos podían reclamar a los tribunales sus derechos y sus legítimos prejuicios, así como exigir una reparación por las injurias recibidas, sea quien fuera el ofensor.

$3^{\circ}$ ) Una sociedad justa fue luego identificada con una sociedad construida sobre los moldes de la ciudadanía. La justicia se tenía por "justa", cuando participaban de ella los ciudadanos de pleno derecho, no los siervos ni los esclavos. En ese esquema los débiles no tenían por qué temer a los fuertes; al contrario, los fuertes llegaban a temblar ante la autoridad de la ciudad (Hobbes).

$\left.4^{\mathrm{a}}\right)$ Locke, Tocqueville, los paladines de las grandes revoluciones y tantos otros proclamaron de palabra o impusieron por la fuerza la equiparación de la sociedad justa con la sociedad formada por individuos libres: sin libertad no hay vida digna ni posibilidad alguna de legitimar ni el poder patrio ni las instituciones del Estado.

$\left.5^{a}\right)$ No menos feroz fue la reclamación de la igualdad económica como sello de garantía para una sociedad justa. Los derechos exigidos en los manifiestos eran y son tildados de papel mojado sin la base de un soporte económico igualitario.

Todas estas identificaciones, nunca cumplidas, hacen más agudo el deseo de una sociedad justa. Pero si buscásemos neuróticamente la "plenitud", comprobaríamos desilusionados deficiencias tan graves como las que siguen: 
1. Se perdería la pluralidad de modelos sociales, dando origen a un prototipo de "ciudad" tan universal como monomorfo.

2. En lugar de estar sujetos al dominio de las leyes racionalmente interpretadas descubriríamos la fría imposición de un Estado absolutamente racional, con derivaciones tan temibles como las que hemos saboreado con amargor en tiempos recientes. ¿Y por qué tememos la dictadura de la racionalidad sobre los ciudadanos? Porque una sociedad "tan" justa puede tornarse fácilmente en una sociedad justiciera.

3. La igualdad total, incluso en la vertiente económica, anularía todo género de proporcionalidad. No queremos equiparar la sociedad justa con una mera repartición de disfrutes y cargas, que reprima la renuncia voluntaria a ciertos bienes, la entrega veleidosa a los placeres, a los juegos, a las locuras afectivas, que imponga un modelo único de convivencia, que sea poco comprensiva con nuestras debilidades, que me obligue a compartir ideales de dudoso valor, etc.

Concluyo: una sociedad completamente justa no es tan justa y, si se me apura, diría que es poco justa y que, a menudo, roza las lindes de lo injusto. ¿Se cierra así el paso a un ansia tan difundida? ¿No existen alternativas para responder a tan inquietante pregunta? Quizás sí, quizás basta iy sobra! con luchar día a día en pro de una sociedad mínimamente justa. 